\title{
Snake Line Performance Applying Single Pixel X-Band MP Radar Data (Case of Mt. Merapi Area, Indonesia)
}

\author{
Ani Hairani ${ }^{1,2 *}$, Adam Pamudji Rahardjo², Djoko Legono², Istiarto ${ }^{2}$ \\ ${ }^{1}$ Department of Civil Engineering, Universitas Muhammadiyah, Yogyakarta, INDONESIA \\ ${ }^{2}$ Department of Civil and Environmental Engineering, Universitas Gadjah Mada, INDONESIA \\ ${ }^{*}$ Corresponding authors: ani.hairani@mail.ugm.ac.id
}

SUBMITTED 5 April 2019 REVISED 15 August 2019 ACCEPTED 16 September 2019

\begin{abstract}
The short-duration-rainfall monitoring techniques have become important recently due to the high demand for disaster risk mitigation. Such techniques produce important information on the rainfall intensity during heavy rainfall in the form of snake line. At the same time, use of X-Band Multi-Parameter Radar (XMP Radar) in rainfall monitoring has increased significantly because of its capacity to cover wide area. An assessment on the snake line performance that was developed based on XMP Radar and ground rainfall monitoring instrument (i.e. Automatic Rainfall Recorder or ARR) has been applied to Mt. Merapi area, Java, Indonesia. Selected rainfall data of November-December 2018 were examined. The assessment used a single pixel of radar data at the location of the ARR. The result shows that rainfall data obtained from XMP Radar are lower than those from ARR. The computed snake line obtained from XMP Radar differs from that from ARR data. The XMP Radar underestimates the warning level by about two level out of four.
\end{abstract}

KEYWORDS XMP Radar; Snake line; ARR; Disaster risk mitigation

(c) The Author(s) 2019. This article is distributed under a Creative Commons Attribution-ShareAlike 4.0 International license.

\section{INTRODUCTION}

\subsection{Disaster Types of Mt. Merapi}

The terms of primary and secondary disasters of Mt. Merapi area have been known for long time. The primary disaster takes place during the eruption period, such as pyroclastic or lava flow, ashfall, ballistic fall, etc. Whereas, the secondary disaster is any disaster occurs beyond eruption period, such as debris flows or lahar flood (Otani, et al., 2018) and (DGWR, 2001). The primary disaster during November 2010 eruption and the secondary disaster afterward caused severe damage to various infrastructures (Table 1).

Heavy rainfall at the beginning of the rainy season after the 2010 eruption has caused debris flow disasters in major rivers in the area (Figure 1). A world cultural heritage, the Prambanan Temple, was threatened by serious damage of debris flow occurrences during the rainy season in November 2010 to March 2011 (Figure 2).
Table 1. Damage and losses due to 2010 Mt. Merapi eruption (BNPB, 2011)

\begin{tabular}{lll}
\hline & Damage/losses & Disaster type \\
\hline Fatality & 383 & Pyroclastic flow \\
Evacuees & 399,400 & Pyroclastic flow \\
Assets/houses & 3,300 & Pyroclastic flow \\
Irrigation fa- & 32 locations & Debris flow \\
cilities & & \\
Bridges & 14 locations & Debris flow \\
Sabo dams & 77 locations & Debris flow \\
Inundation & 6.9 million m $^{2}$ & Debris flow \\
Losses & IDR 4.23 tril- & Pyroclastic and \\
& lion & debris flows \\
\hline
\end{tabular}
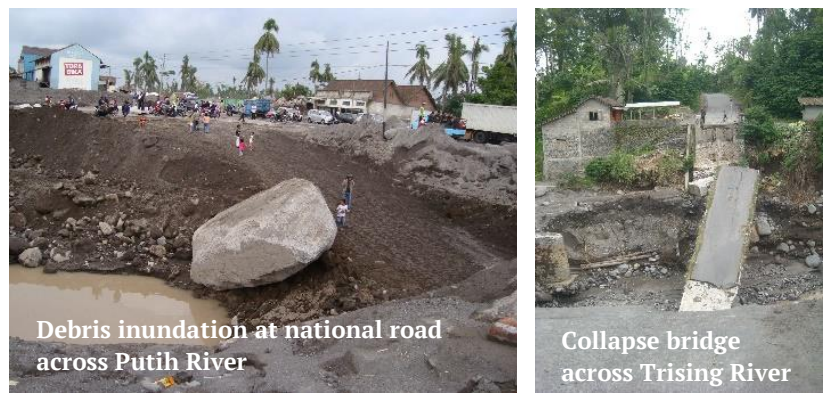

Figure 1. Damages due to debris flow disasters in the aftermath of 2010 Mt. Merapi eruption 


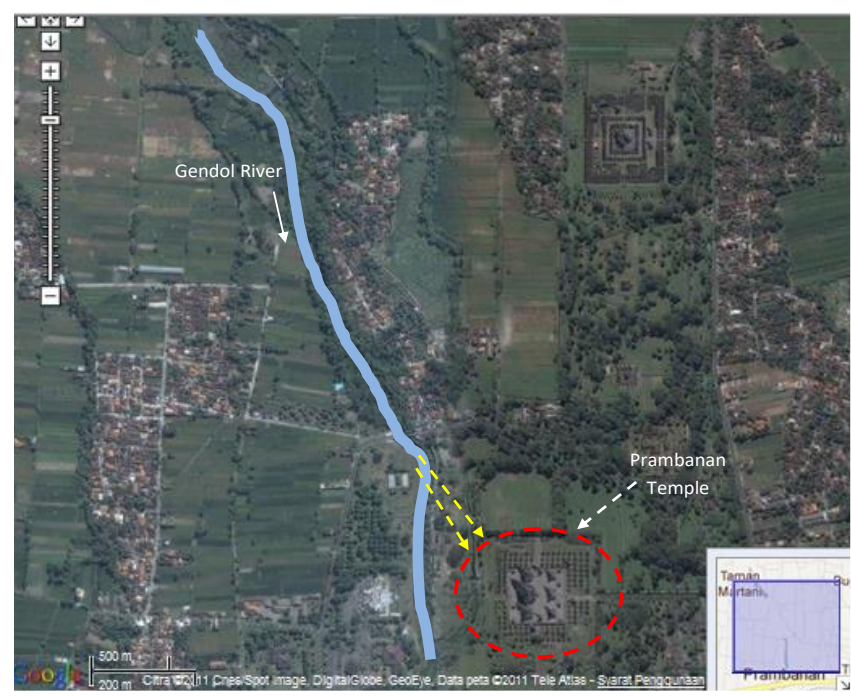

Figure 2. Potential threat of debris flow on the world cultural heritage of Prambanan Temple

In line with the necessity of mitigating the Mt. Merapi secondary disaster, the need of readily available online rainfall data has increased. Ground data gathered from the Automatic Rainfall Recorder (ARR) are considered the most reliable rainfall data. However, the ARR lacks the ability to provide data on spatial distribution of the rainfall. Recent development of radar technology allows the use of X-Band Multi-Parameter Radar (XMP Radar) to gain spatial rainfall distribution almost instantly. This has improved the reliability of rain-induced disaster prediction.

Data provided by XMP Radar are essential in predicting the real-time rainfall monitoring by using snake line method. Snake line is a line tracing the time changes of two rainfall indices. A debris flow warning is released when the snake line passes a threshold indicating that the disaster is about to occur. Sabo Office that is in charge of developing sediment disaster warning system in Mt. Merapi has utilized XMP Radar data in their system. This paper presents assessment of snake line constructed by using XMP Radar rainfall data.

\subsection{Rainfall Characteristics at Mt. Merapi Area}

Many expressions have been introduced to describe the possibility of rainfall occurrence. One of them is the rainfall intensity. The unit of rain- fall intensity is the rainfall depth over time. Depending upon the necessity of the information being grasped, the unit of the rainfall may be different from one to another, in either $\mathrm{mm}$ /hour, $\mathrm{mm} /$ day, or others. For the purpose of the disaster risk mitigation, the rainfall intensity is commonly expressed in $\mathrm{mm} /$ hour. It does not matter if the rainfall depth is collected in a period of less than one hour. Analysis from previous research found, as seen in Figure 3, that the maximum hourly rainfall at Mt. Merapi area took place in the south and southwest part of the area (Prayuda, 2012). Consequently, the rain-triggered debris flow is likely to occur in the south and southwest part of Mt. Merapi area. Nevertheless, the debris flow occurrence also depends on the stability of the sediment source.

\section{INITIATION OF DEBRIS FLOW OCCURRENCE}

\subsection{Natural Instability of Sediment Source}

The sediment source of the debris flow originates from the upper part of the river stream, which has steep slope. Debris flow may be initiated in the upper stream whose slope is steeper than $28^{\circ}$ (Franks \& Woods, 1997). Debris flow can be initiated by unstable sediment layer. Takahashi (1991) explained instability sediment mechanism as a function of the sediment characteristics, i.e. its index properties such as grain and fluid density $\sigma$ and $\rho$, slope angle $\theta$, as well as its internal friction angle $\varphi$, and sediment concentration $C *$ The bed sediment layer might be unstable if $\theta$ satisfies Equation (1).

$\tan \theta \geq\left(\frac{C_{*}(\sigma-\rho)}{C_{*}(\sigma-\rho)+\rho}\right) \tan \varphi$

Equation (1) assumes that the surface flow does not appear or it coincides with the bed layer (Figure 4). The critical index of Takahashi derived from Equation (1) by considering surface flow $h_{0}$ is shown in Equation (2). 


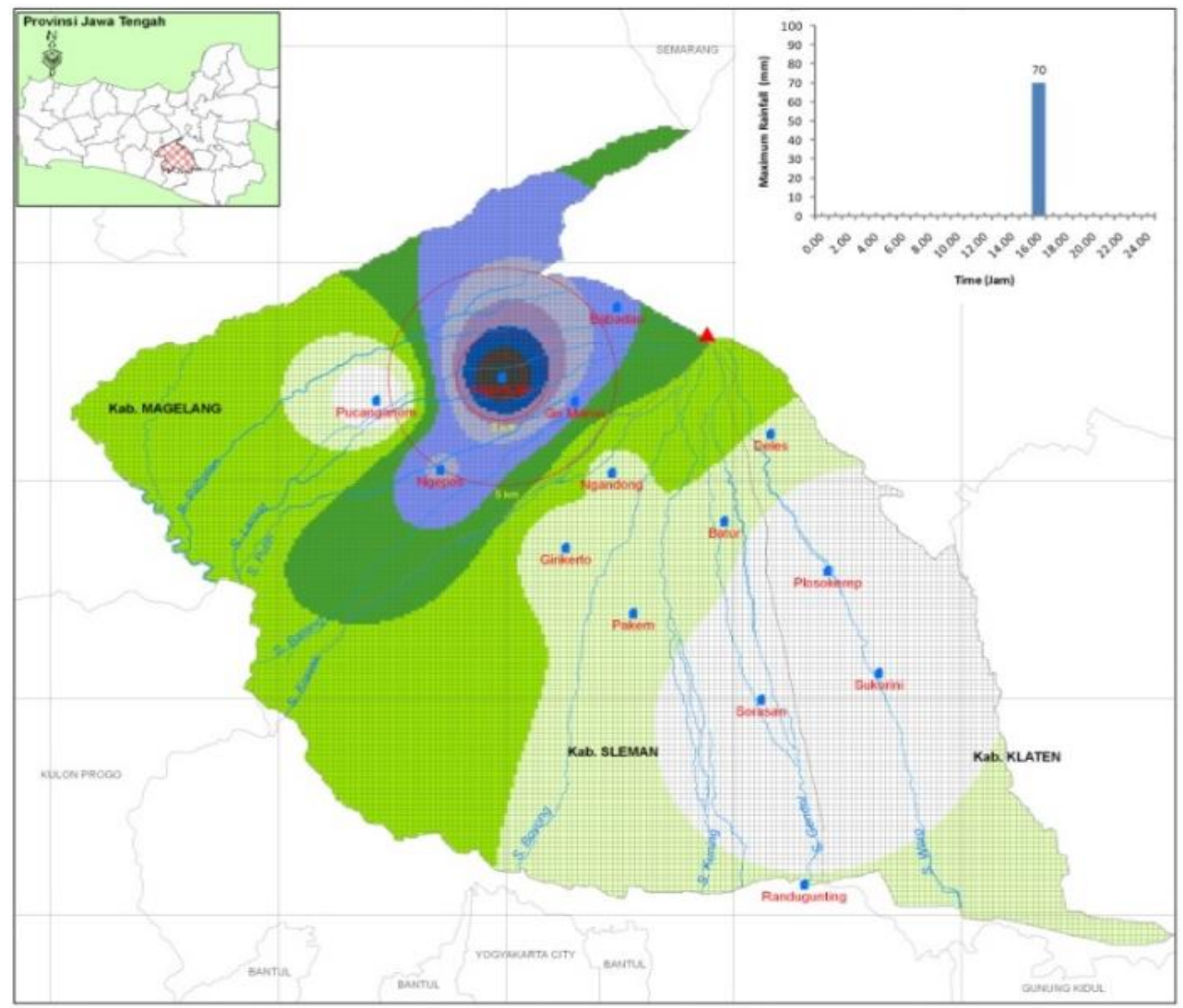

Figure 3. Distribution of maximum hourly rainfall intensity at Mt. Merapi area (Prayuda, 2012).

$$
K=\left(\frac{C_{*}(\sigma-\rho)+\rho\left(1+h_{0} / a_{c}\right)}{C_{*}(\sigma-\rho)}\right) \frac{\tan \theta}{\tan \varphi}
$$

where $a_{c}$ is the depth of confluence of the driving shear-stress line with the resisting shear-stress line. $K$ is defined as the ratio of the driving shearstress to the resisting one. Thus, according to Equation (2), the indicator of debris flow occurrence is the $K$ value exceeding 1 .

The presence of ash volcanic covering sediment layer after the $2010 \mathrm{Mt}$. Merapi eruption has also become a triggering factor of debris flow. Ashfall as the product of eruptive activity caused a significant reduction in soil permeability. It reduces the capability of soil in absorbing water, thus yielding a greater amount of surface flow. As time goes on, the deposited sediment generally becomes more stable due to natural processes, namely interaction of the sediment with the rainfall and other dynamic weathering parameters, and also self-compaction that takes place continuously. It is proved with a diminishing frequency of debris flow occurrence years after the eruption.

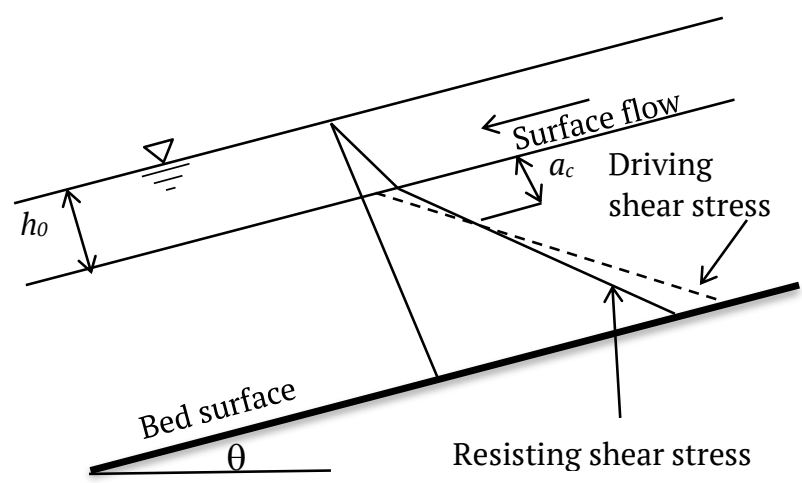

Figure 4. Stress distribution on a sediment layer under the effect of surface flow (Takahashi, 1991) 


\subsection{Human activity affecting the instability of sedi- ment deposit}

One of human activities at Mt. Merapi area is sand mining activity. Such activity has become a dominant factor affecting the instability of the sediment source. For some extent, the sand mining activity has made the deposit unstable because the sediment concentration $C *$ reduces considerably. The sensitivity analysis of the instability of the sediment source based on Equation (2) showed that the declining of the sediment concentration $C$ : from 0.7 to 0.5 has caused $15 \%$ increase in the risk of debris flow occurence. Figure 5 explains sensitivity analysis describing the correlation between the critical index of Takahashi, slope gradient, and sediment concentration.

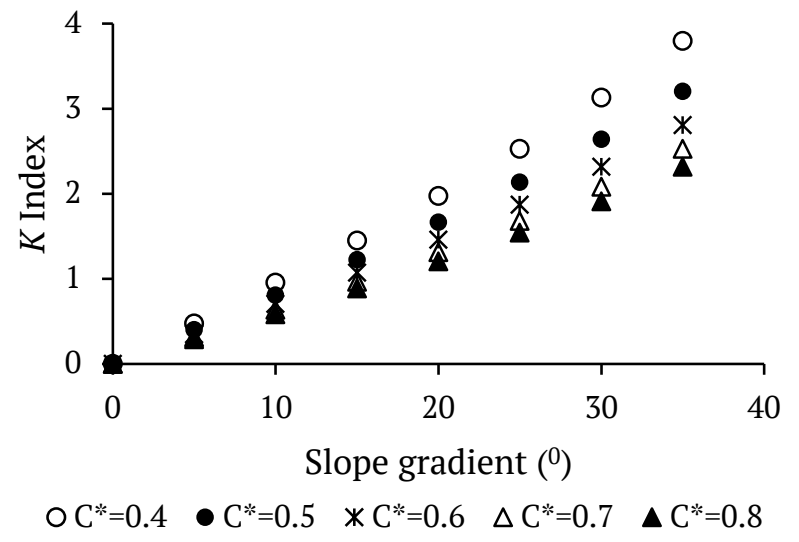

Figure 5. Correlation between critical index of Takahashi, slope gradient, and sediment concentration (Wardoyo, 2013)

\section{RAINFALL MONITORING AT MT. MERAPI AREA}

\subsection{Hydrology and Hydraulics Monitoring System}

The development of monitoring system related to Mt. Merapi activity has been carried out by several institutions. These include the Balai Sabo of the Ministry of Public Works and Settlement and Center for Volcanology and Geological Hazards Mitigation (CVGHM) of the Ministry of Energy and Mineral Resources. CVGHM develops monitoring system related to the volcanic eruption (primary disasters), whereas Balai Sabo develops monitoring system related to the debris flow disaster (secondary disasters). Following Mt.
Merapi eruption in 2006, the Hydraulics Laboratory, Universitas Gadjah Mada, has also been developing hydrology and hydraulics monitoring system at Mt. Merapi area. Through the five years (2015-2019) of research collaboration under the SATREPS (Science and Technology Research Partnership for Sustainable Development), the aforesaid monitoring system has been expanded to cover larger area. The hydrology and hydraulics monitoring system currently being maintained is summarized as follows (see Figure 6.).

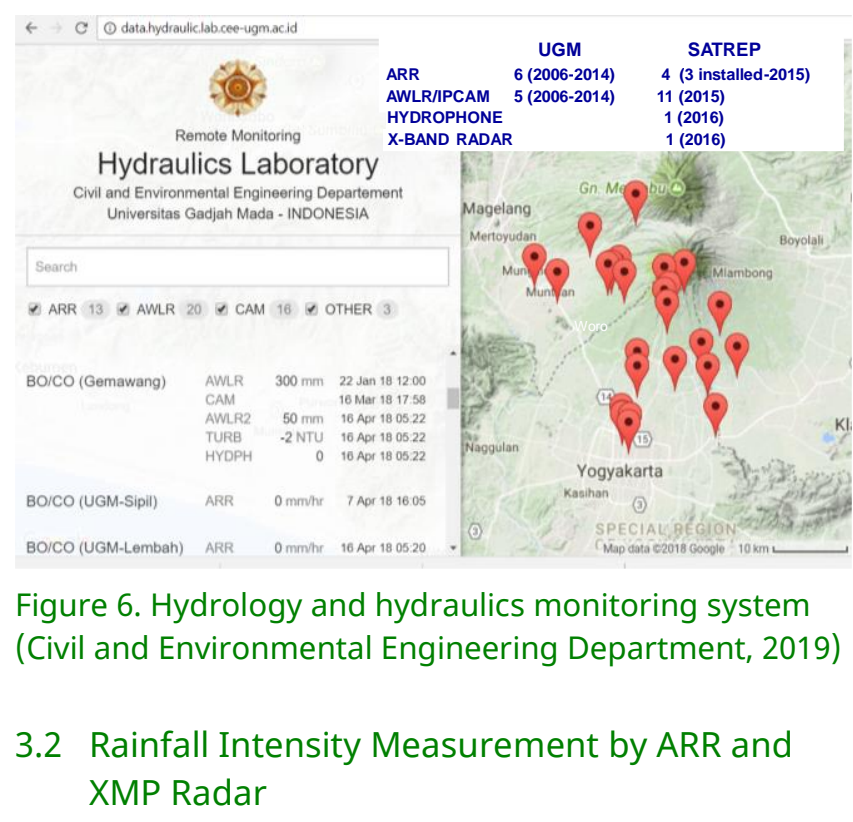

The ARR network at Mt. Merapi area was installed in 2006 by the Hydraulics Laboratory, Department of Civil and Environmental Engineering, Universitas Gadjah Mada. Year 2006 was, therefore, considered as the starting time of the historical development of the real-time monitoring system at Mt. Merapi area initiated by the department. The tipping bucket type with the size of $5 \mathrm{ml}$ and the sampling rate of 3 to 5 minutes have been used, historical data by means of logger are collected, and real-time data are transmitted by GSM internet. Rainfall monitoring by the more advanced technology, i.e. the XMP Radar was introduced five years ago. It was installed at the Merapi Museum (+735 $\mathrm{m}$ asl). XMP Radar captures rainfall in a 150 by 150 sq. m area every 2 minutes. XMP radar applies dual polarimetry which can simultaneously use horizontal and vertical waves, while conventional radar uses either horizontal or vertical wave. XMP radar is widely used to obtain 
rainfall intensity. It can perform better accuracy than previous radar generations, such as the Sand C-band conventional radar. It is also more sensitive and can detect smaller particles due to smaller wavelength (Hambali, et al., 2019).

\subsection{Warning Criteria for Debris Flow Occurrence}

Since Mt. Merapi area has experienced many debris flow occurrences after 2010 eruption, the information on the rainfall intensity at Mt. Merapi area has become more important than before. Such information is required by the communities to identify the initiation of debris flow occurrence.

A further advantage of the availability of the rainfall intensity information persists in the form of the use of the information for the development of warning criteria. The provision of the warning criteria with the information of the growth of the rainfall intensity is an important issue.

Balai Sabo has developed critical line as warning criteria for debris flow according to two rainfall indices, namely hourly rainfall and working rainfall. The critical lines as can be seen in Figure 7 were drawn objectively using Radial Basis Function Network and selected by the concept of capture rate percentage (Putra, et al., 2018). Each critical line indicates debris flow probability level, i.e. Level 1 when there is no risk of flood, Level 2 if there is a risk of flood but not large, Level 3 when there is a high risk of flood evidenced by many flood occurrences recorded in Level 3 in the past, and Level 4 for an extremely high risk of flood (Balai Sabo, 2019).

The warning criteria are also divided into three categories of location based on the slope, i.e. in the range of $10^{\circ}-15^{\circ}, 15^{\circ}-20^{\circ}$ and steeper than $20^{\circ}$. From this critical line, debris flow occurrence can be predicted by real-time rainfall monitoring.

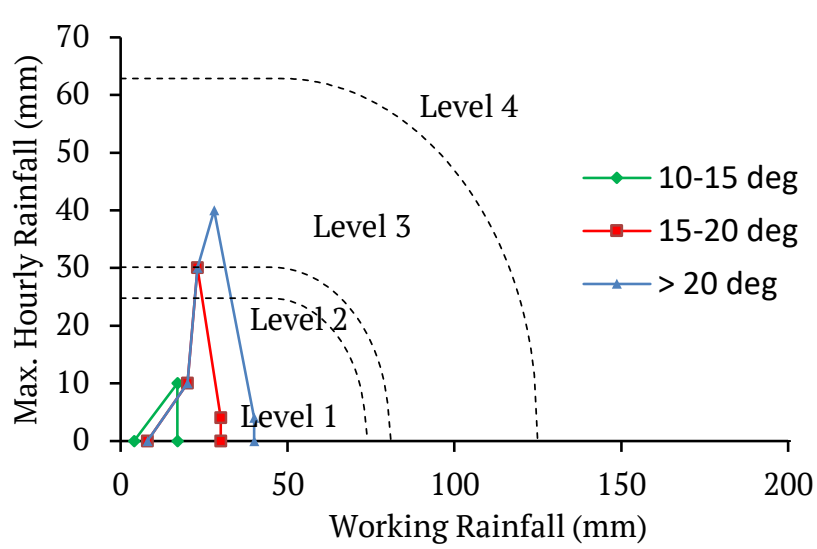

Figure 7. Warning criteria of debris flow occurrence applied in Mt. Merapi (Balai Sabo, 2019).

\section{SNAKE LINE DURING EXTREME CONDITION}

\subsection{Climate Change Issue and Extreme Rainfall}

Issues on the impacts of global warming and climate change to hydro-meteorological behavior in several countries (including Indonesia) have been introduced since the year 2000. Similar conditions have also been found in the Special Region of Yogyakarta.

Figure 8 shows maximum hourly rainfall in Babadan station within 17 years. The figure shows an increasing trend of maximum hourly rainfall. On 28 and 29 November 2017, Cempaka and Dahlia storms attacked Indonesia and caused heavy rainfall. These storms brought high flow at Lower Opak River that caused two bridges, i.e. the Nambangan Bridge and Soka Bridge, collapse. Figure 9 shows the bridges' conditions before and after the collapse.

It was reported that the brides' collapse took place on 28 December 2017, when the river water level reached its highest elevation. The rainfall intensities during 27 to 30 November 2017 recorded at the ARR of BO/CO Station were as follows : 
a) 27 November 2017: $23.47 \mathrm{~mm} /$ day

b) 28 November 2017: $210.28 \mathrm{~mm} /$ day

c) 29 November $2017: 149.45 \mathrm{~mm} /$ day

d) 30 November $2017: 4.79 \mathrm{~mm} /$ day

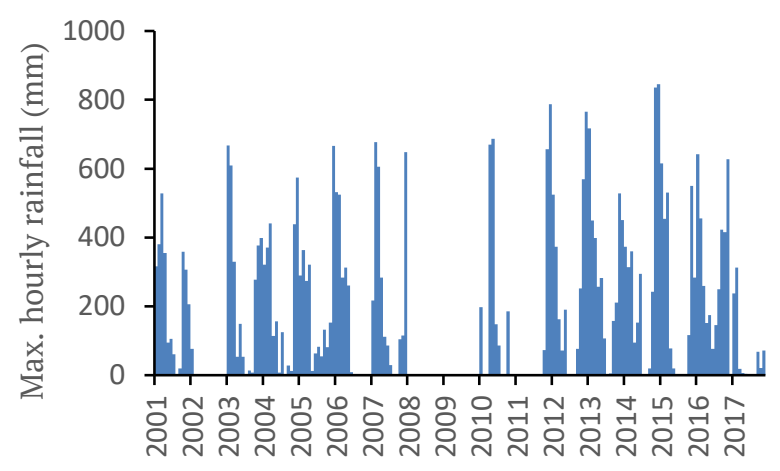

Figure 8. Maximum hourly rainfall in Babadan station (2001-2017)
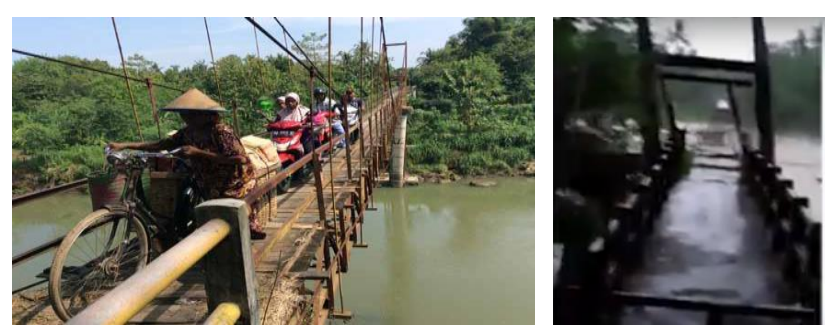

a). Nambangan Bridge (before and after the collapse)
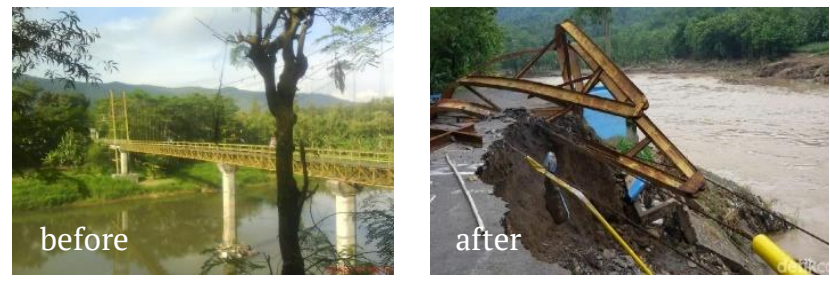

b). Soka Bridge (before and after the collapse)

Figure 9. Damages to Nambangan and Soka bridges due to Cempaka and Dahlia storms

The short duration (5 minutes) rainfall on 28 November 2017 is shown in Figure 10.

\subsection{Snake Line obtained from the ARR and the XMP Radar}

Snake line represents the changes of rainfall indices with time, which can be used to monitor the increase of debris-flow risk level (Yulinsa, 2015). The snake line was created by the Committee for Studying Comprehensive Sediment Control Measures, which was organized by the Ministry of Land, Infrastructure and Transport, Japan. It is considered effective for debris flows because the tank model used for this derivation was found to be effective to predict debris flow occurrence (Ministry of Land, Infrastructure, and Transport (MLIT), 2004). Two rainfall indices were introduced, namely hourly rainfall and working rainfall. Hourly rainfall is a cumulative rainfall within one hour, while working rainfall is calculated using Equation (6). Working rainfall method proposed by MLIT is the accumulation of antecedent rainfall and cumulative rainfall in the series of rain. A series of rain is defined as a continuous rainfall separated by 24 hours or over of no rainfall.

$$
\begin{aligned}
& R W A=\alpha_{1} d_{1}+\alpha_{2} d_{2}+\ldots+\alpha_{14} d_{14}=\sum_{t=1}^{14} \alpha_{t} d_{t} \\
& \alpha_{t}=0.5^{t / T} \\
& R W A=0.25 d_{2}+0.125 d_{3}+0.0625 d_{4}+\ldots . . \\
& R_{W}=\text { Cumulative Rain }+R W A
\end{aligned}
$$

Where $R W A$ is antecedent working rainfall $(\mathrm{mm})$, $\alpha_{t}$ is deduction coefficient at $t$-days before, $d_{t}$ is antecedent rainfall at $t$-days before $(\mathrm{mm}), t$ denotes time before the rainfall (day), $T$ is half-time $($ day $)=1$ day $($ Method $\mathrm{A}), R_{W}$ is working rainfall (mm).

Recently, the use of radar rainfall data has been integrated in the delineation of the snake line and working line. Spatial rainfall data provided by radar monitoring is expected to ease the difficulties in issuing debris flow warning since data from ground rainfall station are limited. Working rainfall represents long term effect of rainfall inducing mass movements. Comparison of working rainfall obtained from radar and ground station is shown in Figure 12. Since there are many data missing both from radar and ground station, only limited data can be assessed. Four cases in the end of 2018 were selected to compare. The assessment used a single pixel of radar data taken at the location of the ground station. Working rainfall from four rainfall events was estimated and depicted in Figure 12. Comparison between working rainfall based on radar and ground station data is somewhat difficult to determine. 


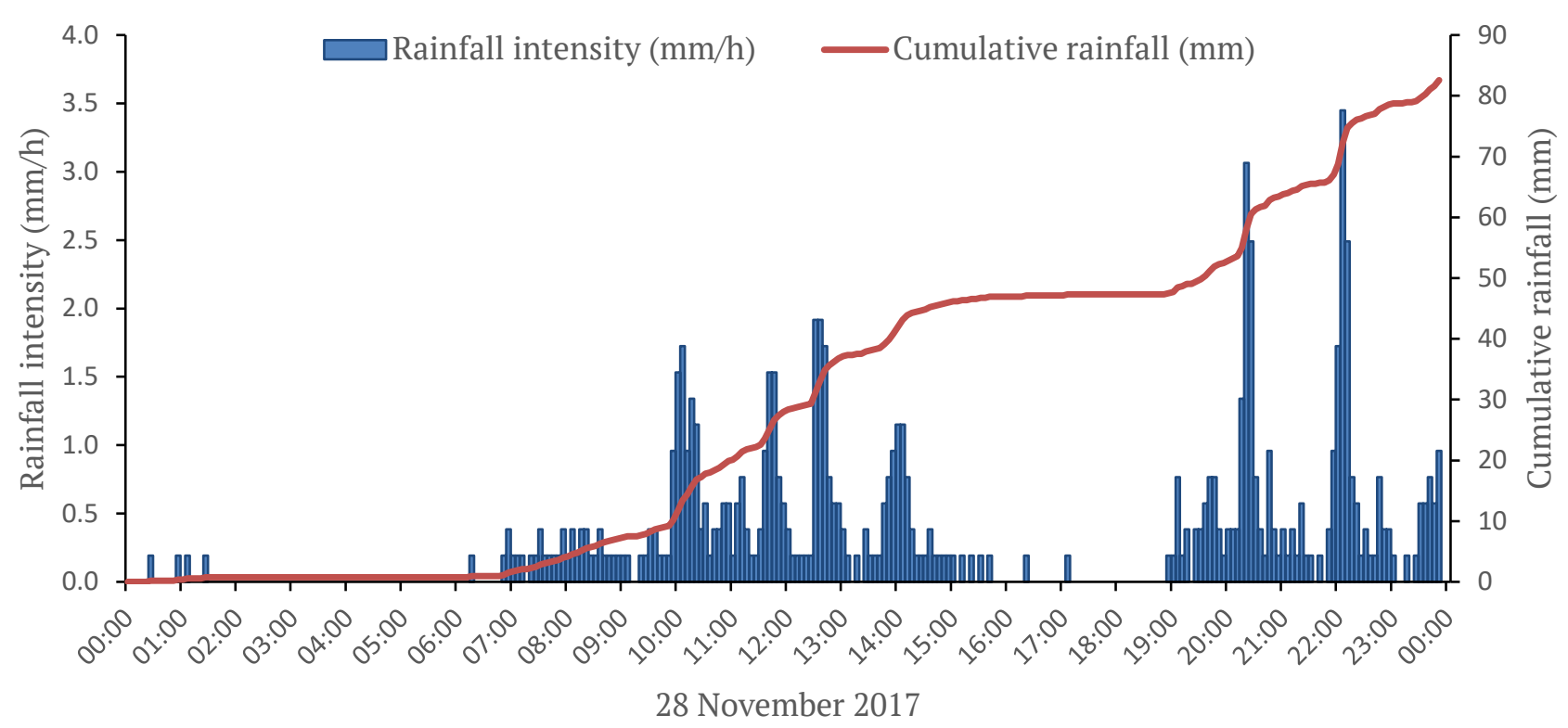

Figure 10. Five-minutes rainfall intensity during 28 November 2017 at ARR-BO/CO Station

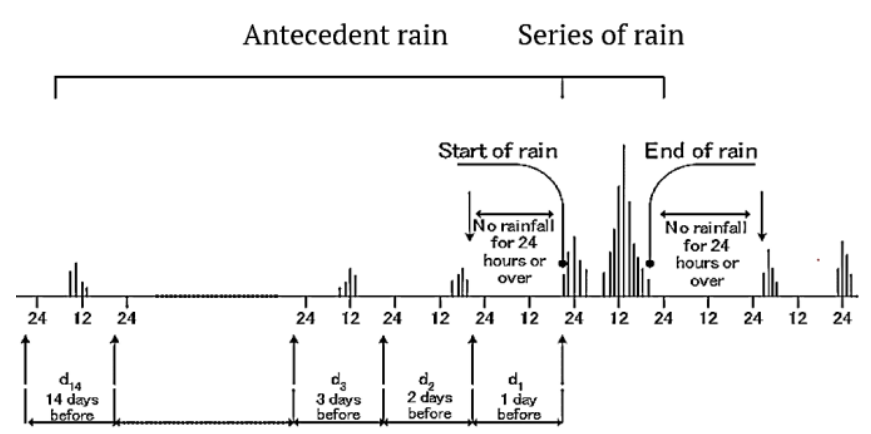

Figure 11. Rain series and antecedent rainfall concept (Ministry of Land, Infrastructure, and Transport (MLIT), 2004).

Degree of discrepancy between working rainfall developed by ARR and X-Band MP Radar varies for each case. However, all cases of rainfall are found below the line of $R_{W}$ radar $=R_{W} \mathrm{ARR}$. It indicates that working rainfall derived from radar is lower than that from ARR. The smallest discrepancy is shown in rainfall event from 8 to 15 December 2018. Implementation of the radar rainfall data on the delineation of snake line in another extreme condition, which was recorded on 8-9 November 2018, is shown in Figure 13(d). Radar rainfall intensity in a 60-minute interval was chosen at the location of ARR PU-D2 station. Figure 13(a) to Figure 13(c) show the distribution of rainfall intensity gained from radar monitoring at, respectively, 14:58, 15:58, and 16:58, on 9 November 2018.

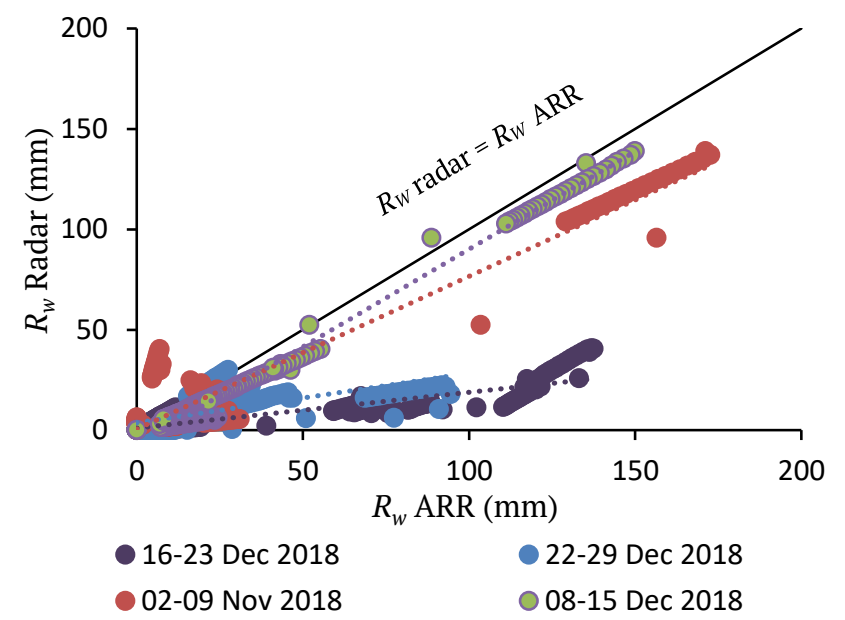

Figure 12. Comparison of working rainfall derived from XMP radar and ARR data

Figure 13(d) shows snake lines based on ground rainfall data (ARR) and X-Band MP Radar rainfall data at the same location, namely PU-D2, with 60-minute interval. Figure 13 clearly shows significant difference between ARR and X-Band MP Radar based snake lines. Data from ARR yields much higher rainfall amount than those of radar. Snake line based on XMP Radar data was generally two levels below that based on ARR data. This case suggests that further study is required on the correlation between radar and ground station rainfall data. 


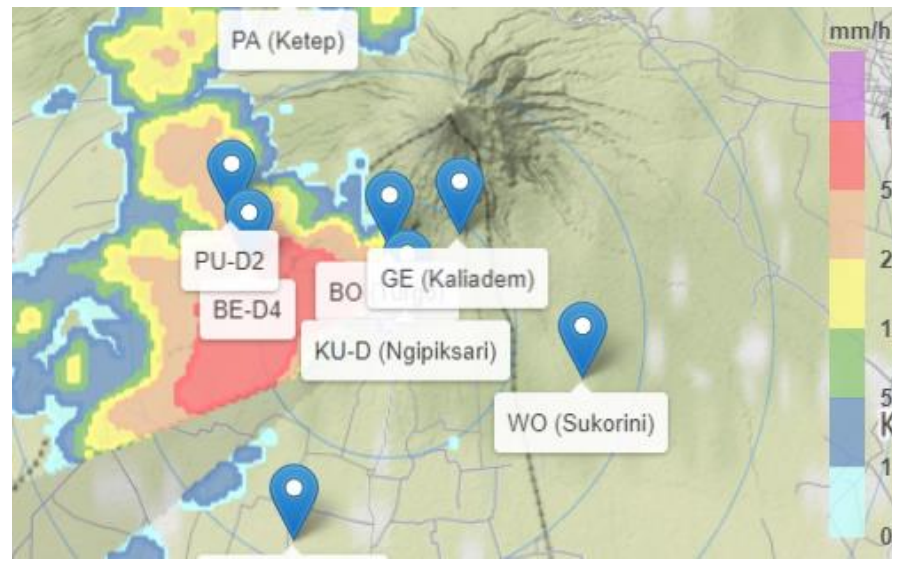

(a)

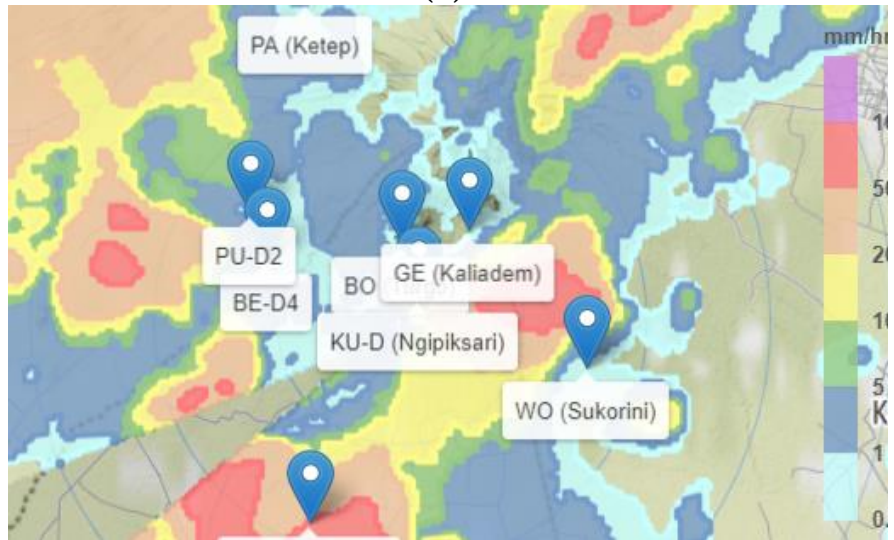

(c)

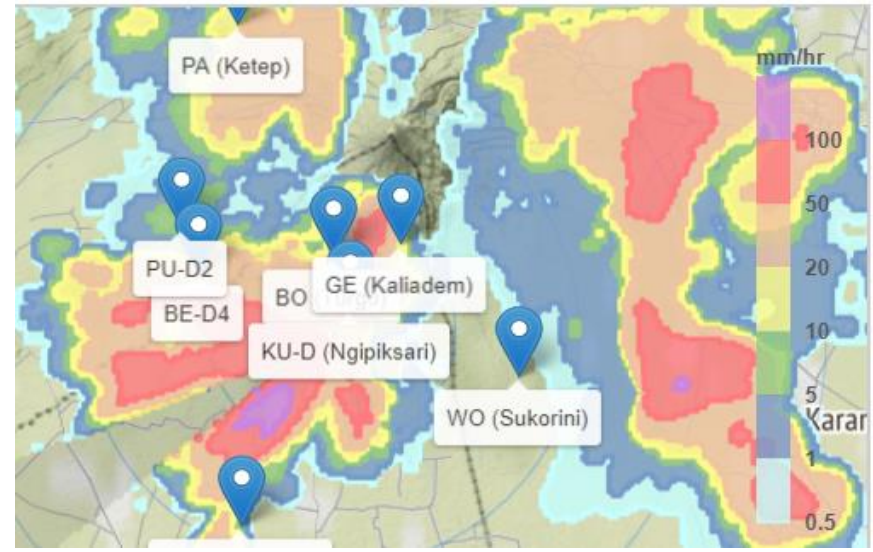

(b)

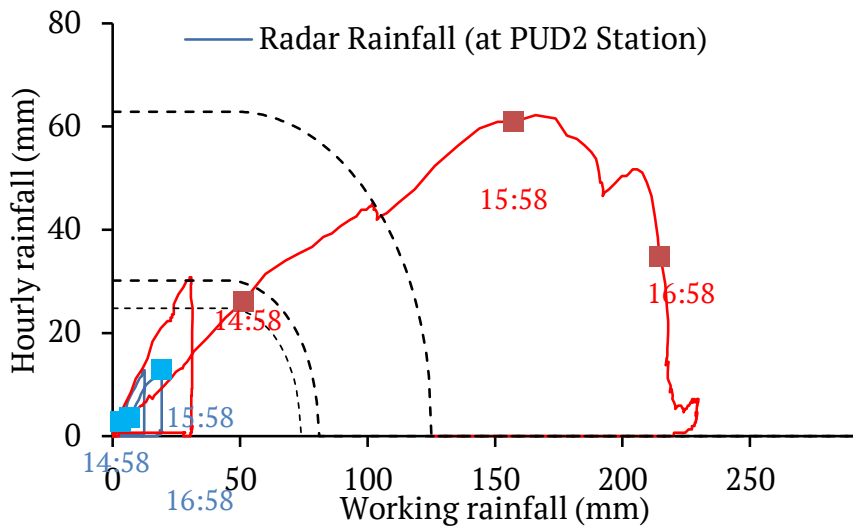

(d)

Figure 13. (a) Rainfall intensity gathered from the XMP Radar at 14:58, 9 November 2018; (b) Rainfall intensity gathered from the XMP Radar at 15:58, 9 November 2018; (c) Rainfall intensity gathered from the XMP Radar at 16:58, 9 November 2018; (d) Comparison of snake line between ARR data and radar data at PU-D2.

\section{CONCLUSIONS}

The working rainfall derived from XMP Radar data is always lower that that derived from ARR data. Accordingly, XMP Radar based snake line underestimates the warning of debris flow by two levels out of four. The snake line of ARR is therefore more critical than that of the XMP Radar.

\section{ACKNOWLEDGMENTS}

The authors express their profound gratitude to the Konsorsium Merapi, notably to Balai Sabo and CVGHM, for the close collaboration during SATREPS Project, and to the Japanese professors who have been involved throughout the five years of SATREPS Project implementation.

\section{REFERENCES}

Balai Sabo, 2019. Sistem Informasi Bencana Sedimen. [Online] Available at: http: //202.173.16.247/test_sdis/monitorcurrent_all.ph p?types=snakelines2 [Accessed 0304 2019].

BNPB, 2011. National Disaster Management Board. [Online] Available at: http://geospasial.bnpb. go.id/[Accessed 6 April 2017].

Civil and Environmental Engineering Department, 2019. Remote Monitoring, Hydraulics Laboratory. [Online] Available at: http: //data.hydraulic.lab.cee-ugm.ac.id/ [Accessed 03 04 2019].

DGWR, 2001. Mt. Merapi and Mt. Semeru Volcanic Disaster Countermeasures Project: Review Master Plan Study, Jakarta: Directorate General of Water Resources (DGWR), Ministry of Public Works Indonesia.

Franks, C. \& Woods, N. W., 1997. Natural Terrain Landslide Study: Preliminary Review of Natural 
Terrain Landslide Hazard Mtigation Measure (Technical Note No.8/97), Hong Kong: Geotechnical Engineering Office.

Hambali, R., Legono, D., Jayadi, R. \& Oishi, S., 2019. Improving Spatial Rainfall Estimates at Mt. Merapi Area Using Radar-Rain Gauge Conditional Merging. Journal of Disaster Research, 14(1), pp. 69-79.

Ministry of Land, Infrastructure, and Transport (MLIT), 2004. Guidelines for Construction Technology Transfer, Development of Warning and Evacuation System against Sediment Disaster in Developing Countries. Infrastructure Development Institute, Japan.

Otani, K., Legono, D., Darsono, S. \& Suharyanto, 2018. Effects of Disaster Management Programs on Individuals' Preparedness in Mount Merapi. Journal of the Civil Engineering Forum, 4(1), pp. 7990.
Prayuda, D. D., 2012. Temporal and Spatial Analysis of Extreme Rainfall on the Slope of Mt. Merapi. Journal of the Civil Engineering Department, 21(3), pp. 1285-1290.

Putra, S. S. et al., 2018. Flood Early Warning System in Mt. Merapi based on Radial Basis Function Network Generated Critical Line. Yogyakarta.

Takahashi, T., 1991. Debris Flow. In: IAHR, ed. Monograph of IAHR. Rotterdam: Balkema, pp. 1165.

Wardoyo, W., 2013. Karakteristik Inisiasi Lahar Terpicu Hujan di Sungai Vulkanik [Characteristics of Lahar Initiation Triggered by Rainfall in Volcanic Stream], Yogyakarta: Dissertation Report, Universitas Gadjah Mada.

Yulinsa, N., 2015. Snake Line Analysis for Lahar Warning System. Journal of the Civil Engineering Forum, 1(1). 
[This page is intentionally left blank] 